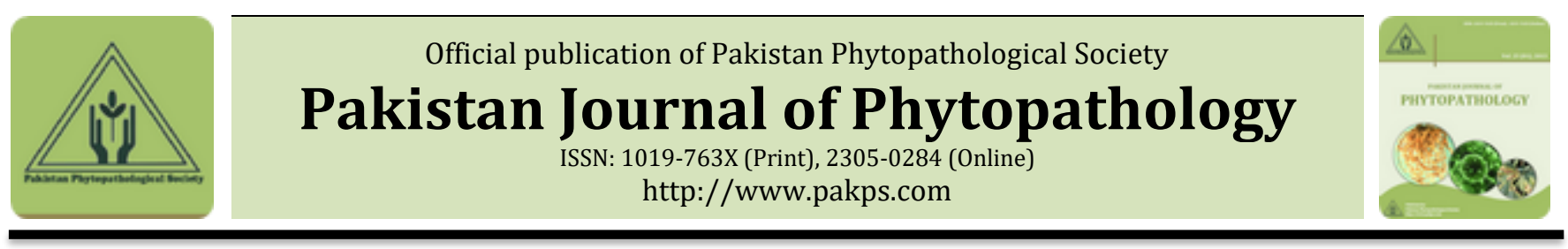

\title{
EXPLOITATION OF NEW CHEMISTRY FUNGICIDES AGAINST CHARCOAL ROT OF SESAME CAUSED BY MACROPHOMINA PHASEOLINA IN PAKISTAN
}

\author{
${ }^{a}$ Muhammad R. Bashir*, bAbid Mahmood, cMuhammad Sajid, d Muhammad A. Zeshan, eMuhammad Mohsan, \\ ${ }^{a} Q$ amar A. T. Khan, eFaizan A. Tahir \\ ${ }^{a}$ Oilseeds Research Institute, Ayub Agricultural Research Institute, Faisalabad, Pakistan. \\ ${ }^{b}$ Director General Agricultural (Res.), Ayub Agricultural Research Institute, Faisalabad, Pakistan. \\ cDepartment of Plant Pathology, Bahauddin Zakariya University, Multan, Pakistan. \\ ${ }^{d}$ Department of Plant Pathology, University of Sargodha, Pakistan. \\ ePlant Pathology Research Institute, Ayub Agricultural Research Institute, Faisalabad, Pakistan. \\ fDepartment of Plant Pathology, University of Agriculture, Faisalabad, Pakistan.
}

\section{A B S T R A C T}

The current research was conducted to find out the most appropriate concentrations of six fungicides for the management of sesame charcoal rot caused by Macrophomina phaseolina under lab and field conditions. The treatments viz. Antracol, Topsin-M, Mancozeb, Score, Topas, Nativo and Control with concentrations of 150, 250 and $350 \mathrm{ppm}$ were used with three replications under completely randomized design and randomized complete block design in Lab. and field conditions respectively. The mean colony growth of all treatments expressed that Nativo exhibited minimum colony growth of $(0.93 \mathrm{~cm})$ as compared to Score $(1.14 \mathrm{~cm})$, Topsin-M $(1.42 \mathrm{~cm})$, Mancozeb $(1.77$ $\mathrm{cm})$, Antracol $(2.04 \mathrm{~cm})$, Topass $(2.33 \mathrm{~cm})$ correspondingly. The interaction between treatments and concentrations $(\mathrm{T} \times \mathrm{C})$ showed that used concentrations $150 \mathrm{ppm}, 250 \mathrm{ppm}$ and $350 \mathrm{ppm}$ of Nativo abundantly inhibit fungal colony growth upto $1.26 \mathrm{~cm}, 0.86 \mathrm{~cm}$ and $0.66 \mathrm{~cm}$ respectively whereas the interaction between treatments and days expressed that after day ninth the minimum colony growth $(1.23 \mathrm{~cm})$ was observed for Nativo as compared to all other treatments. Similarly, the interaction between concentrations and days expressed highest fungal colony growth at concentration $150 \mathrm{ppm}$ on day third $(2.06 \mathrm{~cm})$, sixth $(3.02 \mathrm{~cm})$ and ninth $(3.65 \mathrm{~cm})$ but the interaction of treatments, days and concentrations expressed that at $150 \mathrm{ppm}$ concentration, all treatments exhibited minimum colony growth (1.70 to 3.30$) \mathrm{cm}$ at third, sixth and ninth day as compared to 250 and $350 \mathrm{ppm}$ concentration respectively with respect to control $(6.90 \mathrm{~cm})$. In filed conditions, Nativo exhibited minimum Mean Disease Incidence $(12.55 \%)$ whereas the interaction between treatments and days showed minimum of $14.95 \%, 12.82 \%$ and $9.90 \%$ disease incidence by Nativo as compared to all other treatments including control $(66.86 \%, 77.57 \%$ and $87.22 \%)$ after day tenth, twenty and thirty. It was concluded that Nativo is significantly inhibiting the colony growth under lab and filed conditions.

Keywords: Sesame charcoal rot, Macrophomina phaseolina, invitro and invivo, fungicide evaluation.

\section{INTRODUCTION}

Sesame (Sesamum indicum L.) is the most significant oilseed crop of Pakistan (Anwar et al., 2013). It is cultivated in tropical and subtropical areas of the world

Submitted: October, 13, 2017

Revised: December, 04, 2017

Accepted for Publication: December, 07, 2017

* Corresponding Author:

Email: mrizwan1526@gmail.com

(C) 2017 Pak. J. Phytopathol. All rights reserved. with slightly high temperature (Mensah et al., 2006). The consumption of 100 gram seeds of sesame provide water $(1.60 \mathrm{ml})$, food energy (586 kcal), proteins $(18.08 \mathrm{~g})$, total lipids $(50.87 \mathrm{~g})$, carbohydrate $(24.05 \mathrm{~g})$, total dietary fiber (5.5 g), vitamin $B_{6}(0.816 \mathrm{mg})$, vitamin A (3 $\mu \mathrm{g})$, saturated fatty acids $(1.252 \mathrm{~g})$, monosaturated fatty acids $(3.377 \mathrm{~g}$ ) and polyunsaturated fatty acids (3.919 g) (Nagendra et al., 2012). In the world, it is cultivated on an area of 9398 thousand hectares with total annual production of 4.78 million tons (FAOSTAT, 2015). In 
Pakistan, its area under cultivation is 88 thousand hectares with an average available production of 19.3 thousand tons (Shah et al., 2014).

There are numerous restrains for successful cultivation and production of Sesame crop (Langham and Wiemers, 2002). Among those constraints charcoal rot of sesame caused by Macrophomina phaseolina (Tassi.) Goid. is the most imperative disease of this crop (Dinakaran \& Mohammed, 2001). The losses caused by this disease under field conditions are 57 percent with 40 percent disease incidence whereas yield losses of 5-100 percent has also observed in Egypt under favorable climatic conditions (EL-Bramawy and Abdul Wahid, 2006). Charcoal rot disease has diminished the production of sesame at about 27 million bushels per year in USA (Chattopadhyay and Sastry, 2002) with an estimated value of \$US 146 million (Mame et al., 2014).

Macrophomina phaseolina is necrotrophic and thermophillic phytopathogen in nature (Salik 2007). Although a single specie phaseolina is recognized till now within the genus Macrophomina but a huge variability in morphology and pathogenicity has seen among various isolates from different hosts (Thippeswamy et al., 2003). The pathogen mainly reproduces either through microsclerotia or pycnidia. The fungus spreads promptly through soil as well as seed and enhances the disease severity as soil and air temperature increase from $28-35{ }^{\circ} \mathrm{C}$ (Khan, 2007). The characteristic symptoms of this disease are appearance of spindle shaped lesions, light grey center of leaves with dark border, black secondary roots, sudden wilting and death of growing plants (Khalili et al., 2016).

Numerous disease management approaches are available such as resistant varieties, crop rotation, cultural practices, biological control method, soil solarization, systemic induce resistance and minimum supply of soil moisture to diminish the disease incidence of charcoal rot of sesame caused by Macrophomina phaseolina but these approaches require highly proficient accuracy in measurements as well as long time is required (Infantino et al., 2006). In the meanwhile, adequate application of systemic fungicides against this disease is an appropriate and easy method to practice, prepare solutions, soil drenching and application with irrigation which is quick in action (El-Fiki et al., 2004). Farmers judiciously apply fungicides to protect plants along with enhanced production, yield and economic return
(Arriel et al., 2007). The fungicide application possesses relatively low cost and more effectiveness on crops to hinder disease losses (Azeez and Morakinyo , 2010).

Plant protective measures for soil born diseases depend upon an application of systemic fungicides. The effective management approaches are much imperative to diminish the disease incidence caused by soil born thermophillic plant pathogens which is the most pivotal part of the current research. Moreover, environmentally friendly systemic fungicide is the demand of the existing era. Therefore, it is need of the hour to find out an appropriate concentration of systemic fungicides against charcoal rot of sesame. Thus, the most effective concentrations of systemic fungicides were exploited in the current research to diminish disease losses and prevent sesame plants.

\section{MATERIALS AND METHODS}

Koch's postulate assessment for Macrophomina phaeiolina: Diseased plants with characteristic symptoms of Charcoal rot disease were collected from filed and brought in the oilseeds pathology laboratory for isolation of pathogen. Infected roots were washed thoroughly with tab water and cut into small pieces of 4$6 \mathrm{~mm}$ and surface sterilized with $1 \% \mathrm{NaOCl}$. The roots were dried by keeping on sterilized filter paper in the petri plate. At least 2-3 pieces of infected roots were placed in petri plate containing Potato Dextrose Agar (PDA) medium. The plates were incubated at $\pm 25^{\circ} \mathrm{C}$ for 48-72 hours for fungal growth (Sarwar et al., 2005). Then purified colonies of Macrophomina phaseolina were identified under stereomicroscope (Soesanto et al., 2011).

Sick field preparation: The most susceptible variety of Sesame i.e. TH-6 was grown in Plant Pathology Research Area of Oilseeds Research Institute, Faisalabad. Three successive drenching of pure culture of Macrophomina phaseolina were carried out with irrigation after 15 days interval. Sterilized water @ 3-4 ml was poured on 7-10 days old culture, petri plate was shaked gently and transferred in $250 \mathrm{ml}$ beaker. The no. of spore were counted through haemocytometer by adjusting the spore suspension of $1 \times 10^{6}$ spores $/ \mathrm{ml}$ of $\mathrm{H}_{2} \mathrm{O}$ (Sarwar et al., 2005). After the establishment of disease symptoms, the diseased plants were ploughed in the soil and irrigated to enhance decomposition of plant debris and creating conditions for maximum fungal growth. 
Exploitation of antifungal potential of different fungicides against Macrophomina phaseolina in Laboratory: Six fungicides viz. Antracol, Topsin-M (thiophanate methyl), Mancozeb, Score (Difenconazol), Topas and Nativao (Trifloxystrobin) were assessed through poisoned food technique at three different concentrations $(150,250$ and $350 \mathrm{ppm})$. These fungicides were mixed in PDA medium by putting an appropriate quantity from stock solution. The amended PDA medium with measured quantity of $20-25 \mathrm{ml}$ was poured in petri plates $(9 \mathrm{~cm}$ dia.) under laminar flow chamber. Each plate was replicated three times under completely randomized design (CRD) and incubated at $25 \pm 2{ }^{\circ} \mathrm{C}$ for 10 days. The colony growth was measured after 3,6 and 9 days. $\mathrm{T}_{1}=$ Antracol, $\mathrm{T}_{2}=$ Topsin$\mathrm{M}$,(Thiophanate methyl $70 \% \mathrm{w} / \mathrm{w}), \mathrm{T}_{3}=$ Mancozeb, $\mathrm{T}_{4}=$ Score, (Difenconazol $250 \mathrm{~g} / \mathrm{l}$ ), $\mathrm{T}_{5}=$ Topas, $\mathrm{T}_{6}=$ Nativo, (Tuboconazole 50\% w/w + Trifloxystrobin 25\% w/w) and $\mathrm{T}_{7}=$ Control.

Evaluation of Fungicides in Field conditions against Charcoal rot of Sesame: Most effective concentrations of six fungicides Antracol, Topsin-M (thiophanate methyl), Mancozeb, Score (Difenconazol), Topas and Nativao (Trifloxystrobin) with a control treatment were evaluated against Charcoal rot disease of Sesame caused by Macrophomina phaseolina under field conditions. Susceptible to moderately susceptible varieties/ advanced lines of sesame were collected from Oilseeds Research Institute, AARI, Faisalabad and sown in sick field under randomized complete block design. The recommended $\mathrm{P} \times \mathrm{P}=45 \mathrm{~cm}$ and $\mathrm{R} \times \mathrm{R}=75 \mathrm{~cm}$ distance, fertilizer (60:60:75 NPK) was kept under consideration. Each treatment including control were drenched near root zone with three replications to visualized the impact of fungicides on charcoal rot disease. Data of disease incidence (\%) was recorded with ten days interval up to maturity of crop (Table 1).

$$
\text { Disease Incidence }(\%)=\frac{\text { No. of infected plants }}{\text { Total no. of observed plants }} \times 100
$$

Data analysis: All the statistical tests were performed using SAS/STAT statistical software (SAS Institute, 1990). Means were separated by using Fisher's protected least significant difference (LSD) procedure by taking $\mathrm{P}=0.05 \%$ probability level (Steel, et al., 1997). Analysis of variance (ANOVA), interaction of different treatments and their combinations were developed by using SAS/STAT software package.

\section{RESULTS}

Nativo exhibited minimum colony growth (0.93) as compared to Score (1.14), Topsin-M (1.42), Mancozeb (1.77), Antracol (2.04), Topas (2.33) cm respectively as compared to control (Table 2). Interaction between treatments and concentration $((\mathrm{T} \times \mathrm{C})$ showed that Nativo expressed minimum fungal colony growth at 150 ppm (1.26), $250 \mathrm{ppm}(0.86)$ and $350 \mathrm{ppm}(0.66) \mathrm{cm}$, followed by Score $(1.63,1.00,0.80) \mathrm{cm}$, Topsin-M (2.13, $1.16,0.96) \mathrm{cm}$, Mancozeb $(2.60,1.46,1.26) \mathrm{cm}$, Antracol $(2.93,1.70,1.50) \mathrm{cm}$, Topas $(3.33,2.03,1.63) \mathrm{cm}$ respectively (Table 3 ). The interaction between treatments and days showed that all treatment viz. Nativo (0.63), Score (0.70), Topsin-M (0.83), Mancozeb (1.03), Antracol (1.16), Topas (1.50) expressed minimum colony growth after day three as compared to sixth $(0.99,1.20,1.50,2.00,2.33,2.63$ and 6.56$) \mathrm{cm}$ and $9^{\text {th }}$ day (1.23 to 6.86$) \mathrm{cm}$ respectively (Table 4). Similarly, the interaction between concentrations and days expressed highest fungal colony growth at concentration $150 \mathrm{ppm}$ on day third $(2.06 \mathrm{~cm})$, sixth $(3.02 \mathrm{~cm})$ and ninth $(3.65 \mathrm{~cm})$ respectively as compared to concentration $250 \mathrm{ppm}(1.60,2.31,2.40 \mathrm{~cm})$ and 350 ppm (1.45 to $2.24 \mathrm{~cm})$ on all days with respect to control (Table 5).

Similarly, the interaction of treatments, days and concentrations expressed that Nativo exhibited minimum disease incidence $(0.80,1.20,1.80,0.60,0.90$, $1.10,0.50,0.70,0.80 \mathrm{~cm})$ at all concentrations viz. $150 \mathrm{ppm}, 250 \mathrm{ppm}$ and $350 \mathrm{ppm}$ etc. after 10,20 and 30 days as compared to all other treatments i.e. Antracol, Topsin-M, Mancozeb, Score, Topas, Nativo and control (Table 6).

The mean of all treatments expressed that minimum fungal colony growth was observed at Nativo that was 12.55 percent as compared to other treatments viz. Score (16.46 \%), Topsin-M (32.33\%), Mancozeb (44.32\%), Antracol (52.45 \%), Topas (62.39\%) respectively with respect to control (Table 7). The interaction between treatments and days showed that maximum disease incidence was observed at Topas $(68.42 \%, 63.41 \%, 55.35 \%)$ after ten, twenty and thirty days as compared to other treatments such as Antracol (59.26\%, 52.38\%, 45.72\%), Mancozeb (51.67\%, 43.80\%, 37.50\%), Topsin-M (37.50\%, $33.33 \%, 26.17 \%)$, Score $(19.50 \%, 16.75 \%, 13.14 \%)$ and Nativo $(14.95 \%, 12.82 \%, 9.90 \%)$ as compared to control (Table 8). 
Pak. J. Phytopathol., Vol. 29 (02) 2017. 257-263

Table 1. Disease rating scale for charcoal rot of sesame caused by M. phaseolina

\begin{tabular}{llll}
\hline Disease rating & Description & Response & Symbol \\
\hline 0 & 0 & Immune & $\mathrm{I}$ \\
1 & $1-20 \%$ & Resistant & $\mathrm{R}$ \\
2 & $21-40 \%$ & Moderately resistant & $\mathrm{MR}$ \\
3 & $41-50 \%$ & Moderately susceptible & $\mathrm{MS}$ \\
4 & $51-70 \%$ & Susceptible & $\mathrm{S}$ \\
5 & $71-100 \%$ & Highly Susceptible & HS \\
\hline
\end{tabular}

(Monaim and Ismail, 2010)

Table 2. Impact of various in-vitro chemicals on colony growth of Macrophomina phaseolina (Tassi.) Gold

\begin{tabular}{lll}
\hline Sr \# & Treatments & Colony growth $(\mathrm{cm})$ \\
\hline $\mathrm{T}_{1}$ & Antracol & 2.0444 \\
\hline $\mathrm{T}_{2}$ & Topsin-M & 1.4222 \\
\hline $\mathrm{T}_{3}$ & Mancozeb & 1.7778 \\
\hline $\mathrm{T}_{4}$ & Score & 1.1444 \\
\hline $\mathrm{T}_{5}$ & Topass & 2.3333 \\
\hline $\mathrm{T}_{6}$ & Nativo & 0.9333 \\
\hline $\mathrm{T}_{7}$ & Control & 6.5000 \\
\hline & LSD & 0.0304 \\
\hline
\end{tabular}

Mean values in a column sharing similar letters do not differ significantly as determined by the LSD test $(\mathrm{P} \leq 0.05)$.

Table 3. Impact of various chemicals and concentrations on colony growth of Macrophomina phaseolina (Tassi.) Goid

\begin{tabular}{llll}
\hline \multirow{2}{*}{ Treatments } & \multicolumn{3}{c}{ Colony growth $(\mathrm{cm})$} \\
\cline { 2 - 4 } & \multicolumn{3}{c}{ Concentrations $(\mathrm{ppm})$} \\
\cline { 2 - 4 } & $\mathrm{C}_{150}$ & $\mathrm{C}_{250}$ & $\mathrm{C}_{350}$ \\
\hline Antracol & $2.9333 \mathrm{C}$ & $1.7000 \mathrm{G}$ & $1.5000 \mathrm{H}$ \\
\hline Topsin-M & $2.1333 \mathrm{E}$ & $1.1667 \mathrm{~J}$ & $0.9667 \mathrm{~K}$ \\
\hline Mancozeb & $2.6000 \mathrm{D}$ & $1.4667 \mathrm{H}$ & $1.2667 \mathrm{I}$ \\
\hline Score & $1.6333 \mathrm{G}$ & $1.0000 \mathrm{~K}$ & $0.8000 \mathrm{~L}$ \\
\hline Topass & $3.3333 \mathrm{~B}$ & $2.0333 \mathrm{~F}$ & $1.6333 \mathrm{G}$ \\
\hline Nativo & $1.2667 \mathrm{I}$ & $0.8667 \mathrm{~L}$ & $0.6667 \mathrm{M}$ \\
\hline Control & $6.5000 \mathrm{~A}$ & $6.5000 \mathrm{~A}$ & $6.5000 \mathrm{~A}$ \\
\hline LSD & 0.0811 & & \\
\hline
\end{tabular}

Mean values in a column sharing similar letters do not differ significantly as determined by the LSD test (P $\leq 0.05)$.

$\mathrm{C}_{150}=150 \mathrm{ppm}, \mathrm{C}_{250}=250 \mathrm{ppm}, \mathrm{C}_{350}=350 \mathrm{ppm}$ concentrations

Table 4. Impact of various chemical treatments and days on colony growth of Macrophomina phaseolina (Tassi.) Gold

\begin{tabular}{llll}
\hline & \multicolumn{3}{c}{ Colony growth $(\mathrm{cm})$} \\
\hline Treatments & ${ }^{*} \mathrm{D}_{3}$ & ${ }^{* *} \mathrm{D}_{6}$ & ${ }^{* *} \mathrm{D}_{9}$ \\
\hline Antracol & $1.1667 \mathrm{I}$ & $2.3333 \mathrm{~F}$ & $2.6333 \mathrm{E}$ \\
\hline Topsin-M & $0.8333 \mathrm{~L}$ & $1.5000 \mathrm{H}$ & $1.9333 \mathrm{G}$ \\
\hline Mancozeb & $1.0333 \mathrm{~J}$ & $2.0000 \mathrm{G}$ & $2.3000 \mathrm{~F}$ \\
\hline Score & $0.7000 \mathrm{M}$ & $1.2000 \mathrm{I}$ & $1.5333 \mathrm{H}$ \\
\hline Topass & $1.5000 \mathrm{H}$ & $2.6333 \mathrm{E}$ & $2.8667 \mathrm{D}$ \\
\hline Nativo & $0.6333 \mathrm{M}$ & $0.9333 \mathrm{~K}$ & $1.2333 \mathrm{I}$ \\
\hline Control & $6.0667 \mathrm{C}$ & $6.5667 \mathrm{~B}$ & $6.8667 \mathrm{~A}$ \\
\hline LSD & 0.0811 & &
\end{tabular}

Mean values in a column sharing similar letters do not differ significantly as determined by the LSD test $(\mathrm{P} \leq 0.05)$. ${ }^{*} \mathrm{D}_{3}$ $=$ Day third, ${ }^{* *} \mathrm{D}_{6}=$ Day Sixth, ${ }^{* * *} \mathrm{D}_{9}=$ Day Ninth 
Pak. J. Phytopathol., Vol. 29 (02) 2017. 257-263

Table 5. Impact of various chemical treatments and days on colony growth of Macrophomina phaseolina (Tassi.) Goid

\begin{tabular}{llll}
\hline & \multicolumn{3}{c}{ Colony growth $(\mathrm{cm})$} \\
\hline Concentrations & ${ }^{*} \mathrm{D}_{3}$ & ${ }^{*} \mathrm{D}_{6}$ & ${ }^{* *} \mathrm{D}_{9}$ \\
\hline${ }^{*} \mathrm{C}_{1}$ & $2.0571 \mathrm{~F}$ & $3.0286 \mathrm{~B}$ & $3.6571 \mathrm{~A}$ \\
\hline${ }^{*} \mathrm{C}_{2}$ & $1.6000 \mathrm{G}$ & $2.3143 \mathrm{D}$ & $2.4000 \mathrm{C}$ \\
\hline${ }^{*} \mathrm{C}_{3}$ & $1.4571 \mathrm{H}$ & $2.0143 \mathrm{~F}$ & $2.2429 \mathrm{E}$ \\
\hline Control & $6.0667 \mathrm{C}$ & $6.5667 \mathrm{~B}$ & $6.8667 \mathrm{~A}$ \\
\hline LSD & 0.0461 & & \\
\hline
\end{tabular}

Mean values in a column sharing similar letters do not differ significantly as determined by the LSD test (P $\leq 0.05)$. ${ }^{*} 1$ st $=150 \mathrm{ppm},{ }^{*} 2^{\text {nd }}=250 \mathrm{ppm}$ and ${ }^{*} 3^{\text {rd }}=350 \mathrm{ppm}$ similarly ${ }^{*} \mathrm{D}_{3}=$ Day third, ${ }^{* *} \mathrm{D}_{6}=$ Day Sixth and ${ }^{* * *} \mathrm{D}_{9}=$ Day Ninth expressing colony growth at consecutive days

Table 6. The impact of chemicals, days and concentrations on the development of charcoal rot of sesame

\begin{tabular}{|c|c|c|c|c|c|c|c|c|c|}
\hline \multirow{3}{*}{ Treatments } & \multicolumn{9}{|c|}{ DISEASE INCIDENCE (\%) } \\
\hline & \multicolumn{3}{|c|}{${ }^{*} \mathrm{C}_{1}$} & \multicolumn{3}{|c|}{${ }^{*} \mathrm{C}_{2}$} & \multicolumn{3}{|c|}{${ }^{*} \mathrm{C}_{3}$} \\
\hline & $D_{1}$ & $\mathrm{D}_{2}$ & $\mathrm{D}_{3}$ & $\mathrm{D}_{1}$ & $\mathrm{D}_{2}$ & $D_{3}$ & $D_{1}$ & $\mathrm{D}_{2}$ & $\mathrm{D}_{3}$ \\
\hline Antracol & $1.70 \mathrm{QR}$ & $3.30 \mathrm{~J}$ & $3.80 \mathrm{H}$ & $1.00 \mathrm{XY}$ & $2.00 \mathrm{NO}$ & $2.10 \mathrm{~N}$ & $0.80 \mathrm{Za}$ & $1.70 \mathrm{QR}$ & $2.00 \mathrm{NO}$ \\
\hline Topsin-M & 1.10WX & $2.10 \mathrm{~N}$ & $3.20 \mathrm{~J}$ & $0.80 \mathrm{Za}$ & $1.30 \mathrm{UV}$ & $1.40 \mathrm{TU}$ & $0.60 \mathrm{bc}$ & $1.10 \mathrm{WX}$ & $1.20 \mathrm{VW}$ \\
\hline Mancozeb & $1.50 \mathrm{ST}$ & $2.80 \mathrm{~K}$ & $3.50 \mathrm{I}$ & $0.90 \mathrm{YZ}$ & $1.70 \mathrm{QR}$ & $1.80 \mathrm{PQ}$ & $0.70 \mathrm{ab}$ & 1.50ST & 1.60RS \\
\hline Score & $0.90 \mathrm{YZ}$ & 1.60RS & $2.40 \mathrm{LM}$ & $0.70 \mathrm{ab}$ & $1.10 \mathrm{WX}$ & $1.20 \mathrm{VW}$ & $0.50 \mathrm{c}$ & $0.90 \mathrm{YZ}$ & $1.00 \mathrm{XY}$ \\
\hline Topass & $2.30 \mathrm{M}$ & $3.70 \mathrm{H}$ & $4.00 \mathrm{G}$ & $1.30 \mathrm{UV}$ & $2.30 \mathrm{M}$ & $2.50 \mathrm{~L}$ & $0.90 \mathrm{YZ}$ & $1.900 \mathrm{P}$ & $2.10 \mathrm{~N}$ \\
\hline Nativo & $0.80 \mathrm{Za}$ & $1.20 \mathrm{VW}$ & $1.80 \mathrm{PQ}$ & $0.60 \mathrm{bc}$ & $0.90 Y Z$ & $1.10 \mathrm{WX}$ & $0.50 \mathrm{c}$ & $0.70 \mathrm{ab}$ & $0.80 \mathrm{Za}$ \\
\hline Control & $6.10 \mathrm{E}$ & $6.50 \mathrm{C}$ & $6.90 \mathrm{~A}$ & $5.90 \mathrm{~F}$ & $6.90 \mathrm{~A}$ & $6.70 \mathrm{~B}$ & $6.20 \mathrm{DE}$ & $6.300 \mathrm{D}$ & $7.00 \mathrm{~A}$ \\
\hline LSD & 0.1611 & & & & & & & & \\
\hline \multicolumn{10}{|c|}{$\begin{array}{l}\text { Mean values in a column sharing similar letters do not differ significantly as determined by the LSD test }(\mathrm{P} \leq 0.05) .{ }^{*} \mathrm{C}_{1} \\
=1^{\text {st }} \text { Concentration }(150 \mathrm{ppm}),{ }^{*} \mathrm{C}_{2}=22^{\text {nd }} \text { Concentration }(250 \mathrm{ppm}),{ }^{*} \mathrm{C}_{3}=3 \text { rd } \text { Concentration }(350 \mathrm{ppm}) \text { whereas } \mathrm{D}_{1}= \\
\text { Fungal colony growth after } 10 \text { days, } \mathrm{D}_{2}=\text { Fungal colony growth after } 20 \text { days and } \mathrm{D}_{3}=\text { Fungal colony growth after } 30 \text { days. } \\
\text { Table } 7 \text {. Impact of different in-vivo fungicides on disease incidence due to charcoal rot of sesame }\end{array}$} \\
\hline \multicolumn{2}{|c|}{ Sr. No. } & \multicolumn{4}{|c|}{ Treatments } & \multicolumn{4}{|c|}{${ }^{* *}$ Mean DI $(\%)$} \\
\hline \multicolumn{2}{|l|}{$\mathrm{T}_{1}$} & \multicolumn{4}{|c|}{ Antracol } & \multicolumn{4}{|c|}{$52.453 \mathrm{C}$} \\
\hline $\mathrm{T}_{2}$ & & \multicolumn{4}{|c|}{ Topsin-M } & \multicolumn{4}{|l|}{$32.333 \mathrm{E}$} \\
\hline $\mathrm{T}_{3}$ & & \multicolumn{4}{|c|}{ Mancozeb } & \multicolumn{4}{|l|}{ 44.324D } \\
\hline $\mathrm{T}_{4}$ & & \multicolumn{4}{|c|}{ Score } & \multicolumn{4}{|l|}{$16.466 \mathrm{~F}$} \\
\hline $\mathrm{T}_{5}$ & & \multicolumn{4}{|l|}{ Topass } & \multicolumn{4}{|l|}{$62.393 \mathrm{~B}$} \\
\hline $\mathrm{T}_{6}$ & & \multicolumn{4}{|l|}{ Nativo } & \multicolumn{4}{|l|}{$12.557 \mathrm{G}$} \\
\hline $\mathrm{T}_{7}$ & & \multicolumn{4}{|l|}{ Control } & \multicolumn{4}{|l|}{$77.217 \mathrm{~A}$} \\
\hline
\end{tabular}
LSD 0.1187

Mean values in a column sharing similar letters do not differ significantly as determined by the LSD test $(\mathrm{P} \leq 0.05)$.

${ }^{* *}$ Mean DI = Arithmetic mean of Disease incidence in percentage

Table 8. Impact of treatments and days on disease incidence under field conditions

\begin{tabular}{|c|c|c|c|}
\hline \multirow{3}{*}{ Treatments } & \multicolumn{3}{|c|}{ Disease incidence (\%) } \\
\hline & \multicolumn{3}{|c|}{ Days } \\
\hline & $\mathrm{D}_{10}$ & $\mathrm{D}_{20}$ & $\mathrm{D}_{30}$ \\
\hline Antracol & $59.260 \mathrm{~F}$ & $52.380 \mathrm{H}$ & $45.720 \mathrm{~J}$ \\
\hline Topsin-M & $37.500 \mathrm{~L}$ & $33.330 \mathrm{M}$ & $26.170 \mathrm{~N}$ \\
\hline Mancozeb & $51.670 \mathrm{I}$ & $43.803 \mathrm{~K}$ & $37.500 \mathrm{~L}$ \\
\hline Score & 19.5000 & $16.757 \mathrm{P}$ & 13.140R \\
\hline Topass & $68.420 \mathrm{C}$ & $63.410 \mathrm{E}$ & $55.350 \mathrm{G}$ \\
\hline Nativo & $14.950 Q$ & $12.820 \mathrm{~S}$ & $9.900 \mathrm{~T}$ \\
\hline Control & $66.860 \mathrm{D}$ & $77.570 \mathrm{~B}$ & $87.220 \mathrm{~A}$ \\
\hline \multicolumn{4}{|l|}{ LSD 0.2528} \\
\hline
\end{tabular}




\section{DISCUSSION}

Charcoal rot of sesame caused by Macrophomina phaseolina (Tassi) Goid. is a devastating disease in sesame growing areas of Pakistan (Salik, 2007). The fungus causes huge losses and harm the crop significantly in a wide range of soil temperatures from $25^{\circ} \mathrm{C}$ to $35^{\circ} \mathrm{C}$ (Sagir et al., 2009) which causes yield losses of $5-100 \%$ under an epidemic conditions. Similarly, disease incidence of $40 \%$ was also observed on sesame which consequently reduces the yield upto 57\% under sever conditions (EL-Bramawy and Wahid, 2006).

The sclerotia of pathogen survives in the soil, crop residues and on seed which cause characteristic symptoms such as sudden wilting, destruction of fibrous root, blackening of stem and roots (El-Fiki et al., 2004a). In the absence of resistant germplasm against virulent pathogen, the utilization of systemic fungicides is a potential approach to diminish the inoculum density of soil borne diseases (Reznikov et al., 2016).

In the current research six fungicides viz. Nativo, Score, Topsin-M, Mancozeb, Antracol and Topas were assessed against Charcoal rot disease of sesame caused by Macrophomina phaseolina (Tassi) Goid. with different concentrations. Nativo expressed minimum fungal colony growth $(1.26 \mathrm{~cm}$ at $150 \mathrm{ppm}$ concentration by disrupting the metabolism as well as by hampering the growth and development of pathogen. It binds through covalent bond formation with sclerotia of pathogen and interrupts its ionic concentration (El-Fiki et al., 2004b). The findings of the current research are in line with the studies of Kumar et al. (2016) who assessed Trifloxystrobin 25\% + Tebuconazole 50\% @ 5, 10, 15, and 25 ppm against Macrophomina phaseolina and observed that Nativo expressed significant reduction in colony growth as compared to other fungicides. Chennakesavulu et al. (2013) evaluated six fungicides i.e. carbendazim, tebuconazole, propiconazole, hexaconazole, mancozeb and cheshunt with five concentrations of 50,100, 250, 500 and $1000 \mathrm{ppm}$ against charcoal rot disease pathogen namely Macrophomina phaseolina through poison food technique and diminished that carbendazim, Tebuconazole and propiconazole completely inhibited the mycelial growth of the pathogen even at $50 \mathrm{ppm}$ as compared to all other concentrations.

REFERENCES

Abdel-Monaim, M. F. and M. E. Ismail. 2010. The use of antioxidants to control root rot and wilt diseases of pepper. Notulae Scientia Biologicae, 2: 46.

Anwar, M., T. Bibi, H. S. B. Mustafa, T. Mahmood and M. Ali. 2013. TH-6: a high yielding cultivar of sesame released for general cultivation in Punjab. Advancements in Life Sciences, 1.

Arriel, N. H. C., A. O. Mauro, E. F. Arriel, S. H. UnêdaTrevisoli, M. M. Costa, I. M. Bárbaro and F. R. S. Muniz. 2007. Genetic divergence in sesame based on morphological and agronomic traits. Cropp Breeding and Applied Biotechnology, 7: 253-261.

Azeez, M. A. and J. A. Morakinyo. 2010. Genetic diversity of fatty acids in sesame and its relatives in Nigeria. European Journal of Lipid Science and Technology, 113: 238-244.

Chattopadhyay, C. and R. K. Sastry. 2002. Combining Viable Disease Control Tools for Management of Sesame Stem-Root Rot Caused by Macrophomina phaseolina (Tassi) Goid. Indian journal of plant protection, 30: 132-138.

Chennakesavulu, M., M. Reddikumar and N. E. Reddy. 2013. Evaluation of different fungicides and their compatibility with Pseudomonas fluorescens in the control of redgram wilt incited by Fusarium udum. Journal of Biological Control, 27: 354-361.

Dinakaran, D. and S. Mohammed. 2001. Identification of resistant sources to root rot of sesame caused by Macrophomina phaseolina (Tassi.) Goid. Sesame and Safflower Newsletter: 68-71.

El-Bramawy, M. and A. Wahid. 2006. Field resistance of crosses of sesame (Sesamum indicum L.) to charcoal root rot caused by Macrophomina phaseolina (Tassi.) Goid. Plant Protection ScienceUZPI (Czech Republic).

El-Fiki, A., A. El-Deeb, F. Mohamed and M. Khalifa. 2004. Controlling Sesame charcoal Rot Incited by Macrophomina phaseolina under field conditions by using the resistant cultivars and some seed and soil treatments. Egypt Journal of Phytopathology, 32: 103-118.

El-Fiki, A., F. Mohamed, A. El-Deeb and M. Khalifa. 2004. Some applicable methods for controlling sesame charcoal rot disease (Macrophomina phaseolina) under greenhouse conditions. Egypt Journal of Phytopathology, 32: 87-101.

FAO. 2004. Food and agriculture organization of the United Nations (FAO). United Nations.

G, D. K., N. N and N. S. 2016. Antifungal activity of 
nanofungicide Trifloxystrobin $25 \% \quad+$ Tebuconazole $\quad 50 \%$ against Macrophomina phaseolina. African Journal of Microbiology Research, 10: 100-105.

GROENEWALD, J. Z. and P. W. CROUS. 2014. Genetic diversity in Macrophomina phaseolina, the causal agent of charcoal rot. Phytopathologia Mediterranea, 53: 250-268.

Infantino, A., M. Kharrat, L. Riccioni, C. J. Coyne, K. E. McPhee and N. J. Grünwald. 2006. Screening techniques and sources of resistance to root diseases in cool season food legumes. Euphytica, 147: 201-221.

Khalili, E., M. A. Javed, F. Huyop, S. Rayatpanah, S. Jamshidi and R. A. Wahab. 2016. Evaluation of Trichoderma isolates as potential biological control agent against soybean charcoal rot disease caused by Macrophomina phaseolina. Biotechnology \& Biotechnological Equipment, 30: 479-488.

Khan, S. N. 2007. Macrophomina phaseolina as causal agent for charcoal rot of sunflower. Mycopathology, 5: 111-118.

Langham, D. and T. Wiemers. 2002. Progress in mechanizing sesame in the US through breeding. Trends in new crops and new uses. ASHS Press, Alexandria, VA: 157-173.

Mensah, J., B. Obadoni, P. Eruotor and F. OnomeIrieguna. 2006. Simulated flooding and drought effects on germination, growth, and yield parameters of sesame (Sesamum indicum L.). African Journal of Biotechnology, 5.

Prasad Mn, N., S. Kr and D. S. Prasad. 2012. A Review on Nutritional and Nutraceutical Properties of Sesame. Journal of Nutrition \& Food Sciences,
02.

Reznikov, S., G. R. Vellicce, V. González, V. de Lisi, A. P. Castagnaro and L. D. Ploper. 2016. Evaluation of chemical and biological seed treatments to control charcoal rot of soybean. Journal of General Plant Pathology, 82: 273-280.

SAĞIR, P., A. SAĞIR and T. SÖĞÜT. 2009. The Effect of Charcoal Rot Disease (Macrophomina phaseolina), Irrigation and Sowing Date on Oil and Protein Content of Some Sesame Lines. The Journal of Turkish Phytopathology, 38.

Sarwar, N., I. Haq and F. Jamil. 2005. Induction of systemic resistance in chickpea against Fusarium wilt by seed treatment with salicylic acid and Bion. Pakistan Journal of Botany, 37: 989.

SAS Institute, 1990. SAS/STAT User Guide, Version 6, SAS Institute, Cary, USA.

Shah, A., R. N. Syed, N. Shah, N. Hakro, S. A. Maitlo and M. A. Rajput. 2014. Influence of Some Plant Extracts on Crown Rot Disease of Sesame (Sesamum Indicum L.). Science International, 26.

Soesanto, L., D. Utami and R. Rahayuniati. 2011. Morphological characteristics of four Trichoderma isolates and two endophytic Fusarium isolates. Journal of Scientific \& Industrial Research, 2: 294304.

Steel, R. G., J. H. Torrie and D. A. Dickey. 1997. Principles and procedures of statistics: A biological approach. McGraw-Hill.

Thippeswamy, G., S. Lokesh and V. R. Rai. 2003. Influence of some indigenous medicinal plants extracts on seed mycoflora and seedling growth of some oilseed crop species. Advances in Plant Sciences, 16: 67-74. 